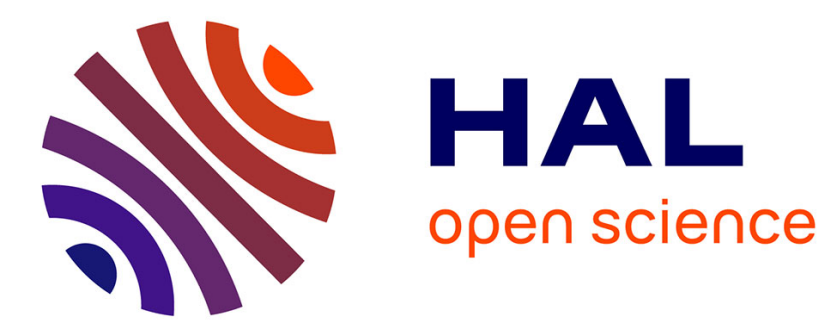

\title{
Trace elements in oceanic pelagic communities in the western Indian Ocean
}

\author{
Nathalie Bodin, Dora Lesperance, Rona Albert, Stephanie Hollanda, Philippe \\ Michaud, Maxime Degroote, Carine Churlaud, Paco Bustamante
}

\section{- To cite this version:}

Nathalie Bodin, Dora Lesperance, Rona Albert, Stephanie Hollanda, Philippe Michaud, et al.. Trace elements in oceanic pelagic communities in the western Indian Ocean. Chemosphere, 2017, 174C, pp.354-362. 10.1016/j.chemosphere.2017.01.099 . hal-01458417

\section{HAL Id: hal-01458417 https://hal.science/hal-01458417}

Submitted on 6 Feb 2017

HAL is a multi-disciplinary open access archive for the deposit and dissemination of scientific research documents, whether they are published or not. The documents may come from teaching and research institutions in France or abroad, or from public or private research centers.
L'archive ouverte pluridisciplinaire HAL, est destinée au dépôt et à la diffusion de documents scientifiques de niveau recherche, publiés ou non, émanant des établissements d'enseignement et de recherche français ou étrangers, des laboratoires publics ou privés. 
Trace elements in oceanic pelagic communities in the western Indian Ocean

Nathalie Bodin ${ }^{1,2^{*}}$, Dora Lesperance ${ }^{2}$, Rona Albert ${ }^{2}$, Stephanie Hollanda ${ }^{2}$, Philippe Michaud ${ }^{3}$, Maxime Degroote $^{1}$, Carine Churlaud ${ }^{4}$, Paco Bustamante ${ }^{4}$

${ }^{1}$ Institute for Research and Development (IRD), UMR MARine Biodiversity Exploitation and Conservation (MARBEC), Fishing Port, Victoria, Mahé Island, Republic of Seychelles

${ }^{2}$ Seychelles Fishing Authority (SFA), Fishing Port, Victoria, Mahé Island, Republic of Seychelles

${ }^{3}$ Ministry of Finance, Trade and the Blue Economy, Victoria, Mahé Island, Republic of Seychelles

${ }^{4}$ LIENSs, UMR 7266, CNRS-Université de La Rochelle, 2 rue Olympe de Gouges, F-17000 La Rochelle, France

*corresponding author : Dr Nathalie Bodin nathalie.bodin@ird.fr 


\section{Abstract}

The mineral composition of target and non-target pelagic fish caught by purse-seiners and longliners in the western-central Indian Ocean was determined. From the ten essential elements analysed, selenium and zinc showed the highest concentrations in swordfish and blue marlin while Indian mackerel appeared as a good source of copper, iron and chrome. All catch had levels of lead and cadmium, two toxic elements, below the maximum sanitary limits. Although some concerns were raised regarding mercury concentrations in the largest species (wahoo, swordfish and blue marlin), molar ratios of mercury and selenium indicate that all oceanic pelagic fish from the western-central Indian Ocean are safe for human consumption. This study also gives insights on the relationships between the levels of essential and toxic elements in fish muscle and the size, trophic position and diet sources of the studied pelagic species.

Keywords: mercury, selenium, seafood, tuna fisheries' bycatch, environmental risk assessment 


\section{Introduction}

Located in the western-central Indian Ocean, the Republic of Seychelles is one of the 52 member states of the Small Island Development States' group of the United Nations. With a land surface of only $459 \mathrm{~km}^{2}$ divided into 115 tropical islands scattered within an Exclusive Economic Zone (EEZ) of 1.3 million square kilometres, the Republic of Seychelles is staking his future growth on the development of a national Blue Economy strategy. The main inter-related challenges for this country include the conservation of ocean ecosystems and biodiversity, the implementation of an integrated cross-sectorial national spatial planning, the increase utilisation of bioresources with respect for those potential new ocean industries as well as for existing ones (eg, shipping, offshore petroleum) of sustainable practises to ensure minimal environmental impact related to their operations, and the maximisation and sustainability of revenues derived from fisheries and fisheries-related sectors. The latter has yet been seriously facing with intense governmental support in the last years to increase national semi-industrial fishing fleets targeting large pelagic species, to facilitate fish export that already represents more than 50\% (mainly tuna and swordfish) of Seychelles total exports, and to encourage research and development in the field of seafood value addition, processing and quality. While such actions should directly benefit to coastal ecosystems by reducing fishing pressure on demersal species that are showing signs of overfishing in Seychelles, they have to be balanced with another important source of revenues that comes from the foreign fishing agreements. Indeed, the Republic of Seychelles is receiving economic benefits through access and licence fees, stemming from the large catches of tuna made by European and Asian purse-seine and longline fleets within its EEZ.

Purse-seine and longline fisheries also take non-target, associated and dependent species, referred hereafter as bycatch. In the case of purse-seiners, it has been estimated to be around $5 \%$ of the total catches which gives a figure of around 12,500 tons of fish species per year in the western Indian Ocean, with some components discarded at sea (Amandé et al., 2012). Although the magnitude and type of discarded bycatch is fishery-specific and highly variable in space and time, fish species with the highest capture probability are the dolphinfish (Coryphaena hippurus), the wahoo (Acanthocybium solandri), the rough triggerfish (Canthidermis maculata), the silky shark (Carcharhinus falciformis), the rainbow runner 
(Elagatis bipinnulata) and marlins (Makaira nigricans, M. indica, Tetrapturus audax). Nowadays, it becomes evident that discard practices constitute a purposeless waste of valuable living resources. It is in this context, and with the aim of promoting the responsible and sustainable management of fishing, that the International and European instances are taking a number of actions oriented to the implementation of "no-discard" and "zero-waste" policies to be followed by the fishing fleets in the near future (IOTC, 2010). With those fisheries policies, a significant increase in bycatch landings is expected in Seychelles. In view of the increasing local population coinciding with a significant drop in the total fish landings from the artisanal fishery, the Republic of Seychelles anticipates that the new influx of bycatch will be a new source of high quality protein for the Nation, hence contributing greatly towards the self-sufficiency and food security of the country where $47 \%$ of current daily animal protein stems from fish (Monnereau and Failler, 2014). One other potential advantage of bycatch landings for the country is to guarantee a reliable availability of raw material to support the initiative of Seychelles to sustainably develop its fisheries post-harvest sector. In such an economic context, it appeared essential for Seychelles to first conduct a nutritional composition study to better estimate the real potential of fish bycatch.

Among the multitude of essential nutrients provided by fish, mineral elements are surprisingly poorly documented despite their important roles in our life functioning as part of numerous enzymes, cofactors and vitamin constituents (Goldhaber, 2003). For instance,zinc $(\mathrm{Zn})$ is a cofactor to more than 300 enzymes involved in important functions such as RNA and DNA metabolism and plays a major role in the stabilization of the structure of a large number of proteins (Chasapis et al., 2012). Manganese (Mn) is involved in protein, lipid and carbohydrate metabolism(NAS, 2002), and its deficiency results in poor reproductive performance, growth retardation, congenital malformations in offspring, and abnormal function of bone and cartilage (Goldhaber, 2003). Selenium (Se) is a critical component of numerous selenoproteins which play major roles in antioxidant systems that actively protect against damage from free radicals and reactive oxygen species, and ultimately could protect against cancer or cardiovascular diseases (Flores-Mateo et al., 2006)(Greenwald et al., 2007). Despite their importance in human nutrition and increasing interest in the last decade in the food industry, most of scientific studies focus on the occurrence in fish flesh of the toxic mineral elements that are mercury $(\mathrm{Hg})$, cadmium $(\mathrm{Cd})$ and lead $(\mathrm{Pb})$, and ultimately conclude with the risks 
for human associated with fish consumption. The nutritional-toxicological conflict related to seafood consumption is being largely discussed at the Commission of the Codex on Contaminants in Food (Codex Alimentarius Commission, 2016), and is of primary concern for both the Food and Agriculture Organization of the United Nations (FAO) and the World Health Organization (WHO). Efforts should now concentrate on the co-evaluation of essential and toxic nutrients in the different commercial fish species with reference to their fishing origin to better advise the general public.

In this context, the present study aims (i) to determine the levels of eleven essential elements (arsenic As, cobalt $\mathrm{Co}$, chromium $\mathrm{Cr}$, copper $\mathrm{Cu}$, iron $\mathrm{Fe}, \mathrm{Mn}$, nickel $\mathrm{Ni}$, Se, silver $\mathrm{Ag}$, vanadium $\mathrm{V}$, and $\mathrm{Zn}$ ) and the three non-essential ones $(\mathrm{Hg}, \mathrm{Cd}, \mathrm{Pb})$ in the muscle of target and non-target oceanic fish species caught in the western-central Indian Ocean and being landed in Seychelles, (ii) to study the influence of fish size and feeding habits on the bioaccumulation of those elements, and (iii) to discuss human exposure benefits and risks with regards to International food safety regulations. A particular attention is given to the balance between $\mathrm{Hg}$ and Se levels in fish flesh as Se is believed to protect against the toxic effects of $\mathrm{Hg}$, particularly its organic methyl-Hg form (Park and Mozaffarian, 2010).

\section{Material and methods}

\subsection{Sample collection}

Thirteen oceanic species were caught by industrial fishing vessels in the western-central Indian Ocean during the northeast monsoon season (November 2014 - February 2015). Samples and data were carefully collected by fishermen and observers onboard longliners and purse-seiners, respectively. Fishing location and length measurement (lower-jaw-fork length - LFL - for billfishes; fork length - FL - for other pelagic species) to the nearest $\mathrm{cm}$ were recorded for each fish. A sample of around $20 \mathrm{~g}$ (wet weight, ww) was then taken from the dorsal white muscle (sampled under the dorsal spine on the left side) and kept frozen until landing (maximum duration 21 days). Samples were then carefully divided into two sub-samples and stored at $-80^{\circ} \mathrm{C}$ until specific lab analyses. 


\subsection{Total lipid content determination and stable isotope analysis}

Muscle sub-samples were freeze-dried and ground up to a fine homogeneous powder with a ball mill MM200 (Retsch). The moisture content (i.e., water content) in the muscle of each species was estimated as the difference of the sample's wet mass (before freeze-drying) and dry mass (after freeze-drying), divided by the sample's wet mass and expressed in percent.

Aliquot of $350 \pm 100 \mathrm{mg}$ were extracted with $8 \mathrm{ml}$ of dichloromethane at $100^{\circ} \mathrm{C}$ under 1900 psi for 10 minutes using a Dionex ASE 200 Accelerated Solvent Extractor to determine the total lipid content (TLC) expressed in \% of dry weight (dw) (Bodin et al., 2009). Carbon and nitrogen stable isotopes were analyzed together on dried lipid-free samples. Isotopic ratios were determined on a Delta $V$ Advantage isotope ratio mass spectrometer interfaced to a Flash EA 1112 elemental analyzer with a Conflo IV interface (EA-IRMS, Thermo Scientific) at the LIENSs facility (La Rochelle, France). The results were reported in the $\delta$ unit notation and expressed per mil (\%) relative to international standards (Vienna-Pee Dee Belemnite for Carbon and atmospheric $\mathrm{N}_{2}$ for Nitrogen). Estimates using replicate measurements of internal laboratory standards (USGS-24, IAEA-CH6, -600 for Carbon; IAEA-N2, -NO-3, -600 for Nitrogen) gave an analytical variability of less than $0.15 \%$ for both $\delta^{13} \mathrm{C}$ and $\delta^{15} \mathrm{~N}$.

\subsection{Trace element analysis}

Analysis of $\mathrm{Hg}$ was performed on both wet and dried sub-samples of fish muscle at the Seychelles Fishing Authority facility (Victoria, Seychelles). Aliquots of 10 to $50 \mathrm{mg}$ dry weight (dw) and of 50 to $100 \mathrm{mg}$ wet weight (ww) were analysed in triplicate directly on a DMA-80 Dual cell (Milestone, Italy). The calibration of the system was performed within a large range using a multi-point calibration curve to define the linearity range of the detector for $\mathrm{Hg}$ (13 points ranging from $5 \mu \mathrm{g} . \mathrm{kg}^{-1}$ to $10 \mathrm{mg} \mathrm{kg}^{-1}$ ). Blanks were run between each analysed sample to reach $0.1 \mathrm{ng}$ of $\mathrm{Hg}$, and two laboratory working controls corresponding to large homogenized wet samples of bigeye tuna white muscle BET-M $\left(\mathrm{Hg}=0.141 \pm 0.004 \mathrm{mg} \cdot \mathrm{kg}^{-1} \mathrm{ww}\right)$ and liver BET-L ( $\mathrm{Hg}=0.986 \pm 0.036 \mathrm{mg} . \mathrm{kg}^{-1} \mathrm{ww}$ ) as well as the certified reference material IAEA-436 (tuna fish flesh homogenate; $\mathrm{Hg}=4.19 \pm 0.36 \mathrm{mg} \cdot \mathrm{kg}^{-1} \mathrm{dw}$ ) were routinely analyzed every $15-20$ samples allowing for comparisons across runs. Satisfactory accuracy (97-104\%) was calculated with an analytical variability 
below $5 \%(n=29)$. Quantification limits was calculated from blank measurements with $\mathrm{Hg}$ values of 0.008 $\mu \mathrm{g} \cdot \mathrm{g}^{-1} \mathrm{dw}$.

Analysis of 13 trace metals was performed on dried samples of fish muscle at the LIENSs facility (La Rochelle, France) according to (Bustamante et al., 2008). Briefly, aliquots of 50 to $300 \mathrm{mg}$ were digested with a mixture of hydrochloric and nitric acids in a microwave. $\mathrm{As}, \mathrm{Cr}, \mathrm{Cu}, \mathrm{Fe}, \mathrm{Mn}, \mathrm{Ni}, \mathrm{Se}$ and $\mathrm{Zn}$ were analyzed by inductively coupled plasma atomic emission spectrometry on a Varian Vista-Pro ICP-OES, and $\mathrm{Ag}, \mathrm{Cd}, \mathrm{Co}, \mathrm{Pb}$ and $\mathrm{V}$ were analyzed by inductively coupled plasma mass spectrometry on an ICP-MS II Series Thermo Fisher Scientific. The analytical performances for each trace element and method were checked using two certified reference materials: dogfish liver NRCC-DOLT-4 and lobster hepatopancreas NRCCTORT-3. Quality control results are summarized in Table 1 showing recoveries ranging from 80 to $114 \%$ according to the element.

Trace element concentrations measured in fish muscle are presented in $\mu \mathrm{g} \cdot \mathrm{g}^{-1}$ (=ppm=parts per million) on a wet weight basis in the present document. ppm is the unit used by state and federal agencies when communicating with the public generally, and when discussing risk from fish consumption.

\subsection{Statistics}

For each fish, the $\mathrm{Hg}: \mathrm{Se}$ molar ratio (noted as MHg:MSe) was calculated from the $\mathrm{Hg}$ and Se levels by dividing concentration (in ppm ww) by the molecular weight (200.59 for $\mathrm{Hg}$ and 78.96 for Se). In addition, the Selenium Health Benefit Value (HBVSe) was calculated according to (Ralston et al., 2015):

$$
\text { HBVSe }=([\mathrm{MSe}-\mathrm{MHg}] / \mathrm{MSe}) \times(\mathrm{MSe}+\mathrm{MHg})
$$

The influence of fish species on fat content, isotopic ratios, trace element levels, MSe:MHg and HBVSe was tested by one way ANOVA followed by Tukey's HSD post hoc test when hypotheses for normality and homoscedasticity were met, or by means of Kruskal-Wallis tests followed by Wilcoxon tests for independent samples. Spearman correlations were used to examine the relationship between the trace metal levels, MSe:MHg or HBVSe, with the biological data (e.g. fish size, $\delta^{13} \mathrm{C}$ and $\delta^{15} \mathrm{~N}$ ). This method was 
also applied to detect dependencies among trace metal concentrations. All statistical analyses were performed using R 2.15.2 software (access Core Team 2016).

\section{Results}

\subsection{Biological data}

The characteristics of the 13 oceanic pelagic fish are presented in Table 2. Species differed with their muscle fat content (Kruskal-Wallis, $\mathrm{H}=72.56$, $\mathrm{p}$-value $<0.001$ ) and were categorized into three groups: (ii) lean fish with a mean TLC below 5\% dw includes the four tunas (skipjack, yellowfin, bigeye and albacore), the dolphin fish, the blue marlin and the wahoo, (ii) low fat fish with a mean TLC between 5 and $10 \%$ dw (silky shark, rainbow runner, rough triggerfish and giant grouper), and (iii) fatty fish with a mean TLC higher than $10 \%$ dw including the swordfish and Indian mackerel (14 and $26 \% \mathrm{dw}$ respectively).

Species also differed with their isotopic signatures $\left(\delta^{15} \mathrm{~N}\right.$ : ANOVA, $F=18.89, p$-value $<0.001 ; \delta^{13} \mathrm{C}:$ ANOVA, $F$ $=24.21, \mathrm{p}$-value < 0.001). Nitrogen and carbon isotopic ratios were highly positively correlated in the studied pelagic food web (Pearson's test: rho=0.64, p-value $<0.001$; Supplementary material Fig. S1), and both trophic tracers were positively correlated with fish size (Spearman's test on all species mixed; $\delta^{13} \mathrm{C}$ : rho $=0.43, \mathrm{p}$-value $<0.001 ; \delta^{15} \mathrm{~N}$ : rho $=0.61, \mathrm{p}$-value $<0.001 ;$ Supplementary material Fig. S1). $\delta^{13} \mathrm{C}$ ranged from $-17.7 \pm 0.2 \%$ o $(\min =-18.4 \%$ ) for rough triggerfish to $-15.4 \%$ o for giant grouper, and the total length of the carbon isotopic chain was $3.0 \%$ o. $\delta^{15} \mathrm{~N}$ ranged from $11.5 \pm 0.6 \%$ o $(\mathrm{min}=10.5 \%$ o for skipjack tuna to $14.8 \pm 0.4$ ( $\max =14.9 \%$ ) for swordfish, and the total length of the nitrogen isotopic chain was $4.4 \%$.

\subsection{Distribution of trace elements in oceanic pelagic fish}

Except for $\mathrm{Ag}, \mathrm{Co}$, and $\mathrm{V}$ whose levels were below the method quantification limits, other trace elements were successfully detected in the muscle of oceanic pelagic fish (Table 2; online supplementary material Table S1). Fe and Zn, both essential nutrients, had the highest concentrations of all elements found in all biota, ranging from 1.0 ppm ww Fe in yellowfin tuna to 12.7 ppm ww Fe in swordfish, and from 2.2 ppm ww Zn in albacore tuna to 17.9 ppm ww Zn in swordfish. With only 37 and $40 \%$ of data above the method 
quantification limits respectively, $\mathrm{Ni}$ and $\mathrm{Pb}$ exhibited the lowest concentrations, ranging from $4.2 \mathrm{e}-4 \mathrm{ppm}$ ww Ni and 1.7e-4 $\mu \mathrm{g} \cdot \mathrm{kg}^{-1} \mathrm{ww} \mathrm{Pb}$ in albacore tuna to 12.2e-2 ppm ww Ni in swordfish and 8.7e-2 ppm ww Pb in swordfish.

Species differed with their muscle Hg content (Kruskal-Wallis, $\mathrm{H}=111.20$, $\mathrm{p}$-value $<0.001$; Table 2, Fig. 2). The highest mean $\mathrm{Hg}$ concentrations, ranging from 0.74 to $1.33 \mathrm{ppm}$ ww, were measured in wahoo, followed by swordfish, giant grouper, and blue marlin. Albacore, bigeye and yellowfin tunas exhibited intermediate Hg levels, around 2 to 4 times lower than the former group. Finally, skipjack tuna, dolphinfish and silky shark had mean $\mathrm{Hg}$ levels ranging from 0.18 to $0.20 \mathrm{ppm}$ ww, while the lowest concentrations ( $\mathrm{Hg}$ $<0.07 \mathrm{ppm} w \mathrm{w}$ ) were found in rainbow runner, Indian mackerel and rough triggerfish. The strongest intraspecific variability of $\mathrm{Hg}$ concentrations was observed for the largest pelagic species (e.g., variance $=0.75$, 0.48 and 0.20 for blue marlin, wahoo and swordfish, respectively). Hg was positively correlated with fish size (Spearman's test; rho $=0.72, \mathrm{p}$-value $<0.001$; Table 3$)$ and $\delta^{15} \mathrm{~N}($ Spearman's test; rho $=0.52, \mathrm{p}$-value $<$ 0.001; Table 3, Supplementary material Fig. S2).

Significant differences between species were found in all other elements' concentrations (Table 3, Fig. 3). $\mathrm{Cd}, \mathrm{Ni}, \mathrm{Pb}$, and $\mathrm{Zn}$ exhibited similar trends with low levels and variations among species, the highest being measured in swordfish. The rough triggerfish had the highest $\mathrm{Mn}$ content while the lowest ones were observed in the two billfish species. $\mathrm{Cr}$ and Fe were about 4 times higher in the mackerel compared to other oceanic fish, although some specimens of swordfish and rainbow runner also exhibited $\mathrm{Cr}$ and $\mathrm{Fe}$ levels in the same range as the mackerel. Cu had the highest levels in bony fish and the lowest in billfish, while the opposite pattern was found for Se. Finally, As was low in most oceanic fish, except in rough triggerfish and silky shark which had As levels more than 7-fold higher. Among elements, Mn showed strong negative correlations with fish size, carbon and nitrogen isotopic values (Table 3, Supplementary material Fig. S2). Cu and Fe tend to decrease with $\delta^{15} \mathrm{~N}$ and fish size respectively, whereas $\mathrm{Cd}$ seems to increase with fish size (Table 3, Supplementary material Fig. S2). Finally, Hg concentrations were positively correlated with Cd, but negatively with Cu and Mn levels (Table 3). 


\subsection{Mercury-selenium interactions}

Mercury:selenium molar ratio (MHg:MSe) and Selenium Health Benefit Value (HBVSe) were calculated for the eight oceanic pelagic fish from the measured muscle $\mathrm{Hg}$ and Se concentrations (Fig. 4).

MHg:MSe ranged from 0.010 in rough triggerfish to 1.01 in wahoo and showed significant inter-specific differences (Kruskal-Wallis, $\mathrm{H}=54.56, \mathrm{p}$-value $<0.001$ ): wahoo and swordfish had the highest mean MHg:MSe value $(0.66 \pm 0.36$ and $0.43 \pm 0.24$, respectively), followed by blue marlin $(0.23 \pm 0.17)$, dolphinfish $(0.12 \pm 0.04)$, rainbow runner $(0.10 \pm 0.04)$, and silky shark $(0.09 \pm 0.10)$, and finally Indian mackerel and rough triggerfish with mean ratio below 0.03 (Fig. 4A).

HBVSe ranged from -0.89 in wahoo to 83.74 in swordfish and significantly varied according to the species (Kruskal-Wallis, $\mathrm{H}=14.33, \mathrm{p}$-value $<0.05)$. The lowest mean HBVSe were observed in rainbow runner (19.81 \pm 2.02$)$ and wahoo $(21.17 \pm 22.45)$, followed by Indian mackerel, dolphinfish, swordfish and rough triggerfish with mean HBVSe from $30.40 \pm 3.56$ to $32.25 \pm 6.02$, to reach finally the highest mean values in blue marlin (51.29 \pm 19.23$)$ and silky shark (52.30 \pm 21.64$)$ (Fig. 4B).

Although those risk exposure indices gave different distribution profiles among the studied oceanic fish, they both highlighted large intra-species variations in the largest pelagic species, i.e. wahoo, blue marlin, and swordfish, with the exception of silky shark which only displayed large variance for HBVSe. Finally, positive relationships were obtained between MHg:MSe and fish size, $\delta^{15} \mathrm{~N}$ and $\delta^{13} \mathrm{C}$ values (Spearman's test: rho $=0.64,0.60$ and $0.64, p$-value $<0.001$ for all), but none between HBVSe and the three biological parameters (i.e. fish size, $\delta^{15} \mathrm{~N}, \delta^{13} \mathrm{C}$ ).

\section{Discussion}

The Food and Agriculture Organisation and the World Health Organisation both recommend that governments monitor the levels of chemical contaminants in food. This recommendation comes in response to increasing concern over the health effects of various contaminants, including metals, found in the food supply. The present study determined the levels and patterns of essential and non-essential trace elements in the flesh of oceanic pelagic communities caught in the western-central Indian Ocean and 
landed in Seychelles. Compared to existing international food safety regulations and literature data, our results contribute to the identification of benefits and risks for Seychelles' population associated with fish consumption. Moreover, we provide information of primary interest on the mineral composition of nontarget pelagic fish for future potential economic valorisation.

\subsection{Comparison with literature and reference values for toxic elements}

Three general categories of $\mathrm{Hg}$ bioaccumulation were identified: high range (mean $\mathrm{Hg}>0.5 \mathrm{ppm} w \mathrm{w}$ ), middle range (between 0.1 and 0.5 ) and low range $(<0.1)$. High range includes the largest pelagic species, i.e. wahoo, swordfish, giant grouper and blue marlin; middle range includes the four tuna species, dolphinfish, and silky shark; low range includes the smallest pelagic species, i.e. rainbow runner, rough triggerfish and Indian mackerel. From those values, none of the individual fish from the 2 latter groups exceeds the maximum limit (ML) of $0.5 \mathrm{ppm}$ ww defined for fish in general by international instances, and only $10 \%$ of the individuals composing the high range group showed $\mathrm{Hg}$ levels higher than the value of 1 ppm ww set up specifically for predatory fish (Codex Alimentarius Commission, 2011; EC, 2011, 2006). Moreover, considering each large pelagic species separately, the main concerns appeared for wahoo with $60 \%$ of the individuals showing a $\mathrm{Hg}$ muscle concentration exceeding $1 \mathrm{ppm}$ ww and with the highest measured $\mathrm{Hg}$ level reaching $2.2 \mathrm{ppm}$ ww. Swordfish and blue marlin both had maximum Hg levels of 1.7 ppm ww, with $30 \%$ of the analysed specimens exceeding $1 \mathrm{ppm} \mathrm{ML.} \mathrm{Swordfish} \mathrm{from} \mathrm{Seychelles} \mathrm{waters}$ showed similar muscle $\mathrm{Hg}$ concentrations than swordfish from Sri Lanka and Reunion Island waters(Jinadasa et al., 2014a, 2014b; Kojadinovic et al., 2006), whereas a 2-fold lower mean value was reported in specimens caught in the Mozambique Channel (see online supplementary material Table S2).

On a global scale, $X$. gladius from the Indian Ocean had similar $\mathrm{Hg}$ bioaccumulation than in the Pacific Ocean and Eastern Atlantic Ocean (e.g., Japan: 1.03 ppm ww, (Yamashita et al., 2011); Hawaii: 1.07士0.60 ppm ww, (Kaneko and Ralston, 2007); Azores: 0.06-4.91 ppm ww, (Branco et al., 2007; Monteiro and Lopes, 1990); Equatorial region: 0.90-2.3 ppm ww (Branco et al., 2007)), whereas swordfish in the Western Atlantic Ocean was 1.5-2-fold less contaminated (e.g., Brazil and Uruguay waters: $0.6 \pm 0.3 \mathrm{ppm}$ ww, (Mendez et al., 2001; Rodrigues et al., 2013); US southern waters: 0.46 \pm 0.24 ppm ww (Cai et al., 2007, 
2006)). Hg values of wahoo reported in this study were surprisingly high (from 0.60 to $2.17 \mathrm{ppm} w w$ ), exceeding by far those reported for similar-size specimens in Reunion Island and Hawaii $(0.13 \pm 0.08$ and $0.25 \pm 0.20 \mathrm{ppm} w w$, respectively; (Kaneko and Ralston, 2007; Kojadinovic et al., 2006). In the 80s, $\mathrm{Hg}$ content 2-fold lower were measured in this species caught in Seychelles waters (see online supplementary material Table S2). On the opposite, blue marlin from Seychelles surrounding waters appeared 3 to 15 times less contaminated than similar-sized fish analysed in Hawaii (Kaneko and Ralston, 2007; Shultz and Crear, 1976; Shultz and Ito, 1978) and Southern US Atlantic waters (Cai et al., 2007, 2006; Luckhurst et al., 2006). Regarding the middle $\mathrm{Hg}$ range group, the values measured in the four tuna species and the dolphinfish in this study were in the same range as in the Indian Ocean (see online supplementary material Table S2), Atlantic Ocean and north Pacific Ocean, whereas (Araújo and Cedeño-Macias, 2016) recently reported $\mathrm{Hg}$ concentrations higher than the ML of $1 \mathrm{ppm}$ ww in the flesh of dolphinfish and yellowfin tuna in Ecuador (1.6 \pm 1.4 and $1.4 \pm 1.3 \mathrm{ppm}$ ww respectively). Finally, within the low $\mathrm{Hg}$ range group, only data for Indian mackerel have been reported in the literature revealing also weak $\mathrm{Hg}$ bioaccumulation for this species in Malaysian waters (Agusa et al., 2005; Khandaker et al., 2015), whereas consumption risks were reported for Indian mackerel caught in Mumbai waters and Bay of Bengal (see online supplementary material Table S2)(Deshpande et al., 2008; Mukherjee and Kumar, 2011).

$\mathrm{Cd}$ and $\mathrm{Pb}$ showed low concentrations in the muscle of the fish from the oceanic pelagic communities, the highest being observed in swordfish (mean values $=0.06$ and $0.01 \mathrm{ppm}$ ww respectively). While a unique ML of 0.3 ppm ww Pb exists for all fish, three MLs have been defined in the case of $\mathrm{Cd:} 0.3,0.1$ and 0.05 ppm ww for billfishes, mackerels, and other fish species, respectively (Codex Alimentarius Commission, 2011; EC, 2011, 2006). Considering those limits, only 2 swordfish from the total number of 76 oceanic fish and 28 swordfish were reported to exceed $\mathrm{Cd} \mathrm{ML}$, and all fish appeared safe for consumption regarding $\mathrm{Pb}$ exposure. Our data were in accordance with $\mathrm{Pb}$ concentrations measured in fish from the Indian Ocean (Annex 2), while higher values ranging from 0.04 to $0.8 \mathrm{ppm}$ ww were reported in dolphinfish, yellowfin and Indian mackerel from Ecuador and Malaysia (Agusa et al., 2005; Araújo and Cedeño-Macias, 2016). Regarding Cd, fish from Seychelles appeared less contaminated than in other regions. For instance, around 3 to 7-fold higher $\mathrm{Cd}$ concentrations were observed in swordfish and dolphinfish from the south-west 
Indian Ocean see online supplementary material Table S2), and levels exceeding more than 100 times our data were measured in Malaysian Indian mackerel and Ecuadorian dolphinfish (Agusa et al., 2005; Araújo and Cedeño-Macias, 2016).

\subsection{Comparison with literature and reference values for essential elements}

Essential elements are micronutrients that need to be daily consumed in adequate amounts in order to sustain normal physiological functions (Goldhaber, 2003). In general, seafood constitutes a good source for metalloid nutrients, but concentrations can diverge greatly between species and thus have to be monitored.

The comparison of observed data with available literature revealed that dolphinfish and swordfish in Seychelles waters had 2-3 times less $\mathrm{Cu}, \mathrm{Fe}$ and $\mathrm{Zn}$ but similar levels of $\mathrm{Mn}$ than these two species caught either in the Mozambique Channel or Reunion Island (Kojadinovic et al., 2007). Moreover, those four elements had levels 3 to 10 times lower in Indian mackerel from Seychelles compared to Malaysia waters (Agusa et al., 2005; Khandaker et al., 2015). Legal thresholds are inexistent for essential elements in Europe. Guidance values in muscle are, however, recommended in some countries, such as $20 \mathrm{ppm}$ ww for $\mathrm{Cu}$ and $50 \mathrm{ppm}$ ww for $\mathrm{Zn}$ (MAFF, 1995). While a previous study reproted individuals of skipjack and yellowfin tunas from south-west Indian Ocean with $\mathrm{Zn}$ concentrations above the recommended value of 50 ppm (maximum Zn levels around 85 and 125 ppm ww, respectively), none of the fish caught in Seychelles waters reached this limit or the one recommended for $\mathrm{Cu}$.

Regarding As, data below 1 ppm ww were reported in Malaysian Indian mackerel and Sri Lankan skipjack (see online supplementary material Table S2) which is in accordance with those measured in the present study. (Storelli et al., 2005) reported wide range of As concentrations in the muscle of Mediterranean swordfish and bluefin tuna reaching $7 \mathrm{ppm}$ ww as observed in rough triggerfish and silky shark from the western-central Indian Ocean. However fish accumulating mainly the non-toxic organic form of As, the concentrations reported in fish flesh in the present study do not pose any issue for health human through fish consumption (Codex Alimentarius Commission, 2011). 
Se is the essential element that has been the most investigated in marine species mainly due its major role in counteracting $\mathrm{Hg}$ toxicity (see section 4.4). Dolphinfish and swordfish exhibited similar muscle Se concentrations in different parts of the western Indian Ocean, i.e. Seychelles, Reunion Island and Mozambique Channel (Kojadinovic et al., 2007). Our results also fit with those reported in Hawaii for blue marlin, wahoo and dolphinfish (Kaneko and Ralston, 2007; Shultz and Crear, 1976; Shultz and Ito, 1978). Swordfish from the western Indian Ocean, however, contained almost 2 times more Se in its flesh compared to specimens inhabiting the Eastern Atlantic Ocean (Azores and equatorial region; (Branco et al., 2007)), the northern Pacific Ocean (Hawaii and Japan; (Kaneko and Ralston, 2007; Shultz and Ito, 1978; Yamashita et al., 2011), and the Mediterranean Sea (Plessi et al., 2001).

4.3. Influence of biological processes on trace elements in oceanic pelagic communities

Fish size, trophic position (nitrogen isotopic signatures, $\delta^{15} \mathrm{~N}$ ) and diet sources (carbon isotopic signature, $\delta^{13} \mathrm{C}$ ) had variable effects on the bioaccumulation of trace elements in oceanic pelagic fish communities depending on the element considered. For instance, a positive exponential relationship between $\mathrm{Hg}$ concentrations and trophic position was observed likely reflecting $\mathrm{Hg}$ biomagnification through the oceanic pelagic food web. This process occurs because consumers feeding at higher trophic levels eat larger prey with higher body burdens that smaller ones. However, our results also revealed that pelagic species may share the same trophic level but different $\mathrm{Hg}$ bioaccumulation patterns. It is the case for example of the rough triggerfish and skipjack tuna, both with a mean $\delta^{15} \mathrm{~N}$ value of around $11.6 \%$ o whereas $\mathrm{Hg}$ concentrations were 7-fold higher in skipjack tuna. Similarly, rainbow runner exhibited $\delta^{15} \mathrm{~N}$ in the same range as bigeye, albacore and yellowfin tunas but had lower $\mathrm{Hg}$ content by a factor 5 to 7 compared to the three tuna species. This can be related to the differences of lifespan between species as suggested by the positive relationship obtained between fish size (proxy of fish age) and Hg muscle levels. Due to its slow elimination rates (half-life on the order of years), $\mathrm{Hg}$ accumulates in tissue as fish consume more food through time leading to higher $\mathrm{Hg}$ contamination of long-lived species such as tunas (e.g., maximum age of 13 and 16 years old for albacore and bigeye tunas, respectively; (Farley et al., 2006; Wells et al., 2013) compared to the middle-lived rainbow runner (max. age $=5$ years old; (Iwasaki, 1995). However, the 
observed difference of $\mathrm{Hg}$ contamination between skipjack tuna and triggerfish with similar lifespan (between 12-15 years; (Burton et al., 2015; Collette and Nauen, 1983) is most likely related to the difference of food sources observed between these two species. Indeed, C. maculata exhibited the lowest $\delta^{13} \mathrm{C}$ values $(-17.7 \pm 0.2 \%$ ) of the oceanic pelagic food web indicating that it feeds on more pelagic-based prey compared to skipjack characterised by intermediate $\delta^{13} \mathrm{C}$ values $(-16.9 \pm 0.3 \%$ ). In addition, the positive relationship between $\mathrm{Hg}$ concentrations and $\delta^{13} \mathrm{C}$ reflects the higher exposure of deep-feeding predators such as swordfish and wahoo compared to surface-feeding species (Goutte et al., 2015). The influence of forage depth on the $\mathrm{Hg}$ body burden of predator species has been reported in different ecosystems including oceanic pelagic food web from waters surrounding Hawaii in the central North Pacific Ocean (Choy et al., 2009; Chumchal et al., 2008; Eagles-Smith et al., 2016; Magalhães et al., 2007). Thus, our study confirmed the complex inter-related determinants that affect $\mathrm{Hg}$ bioaccumulation processes in pelagic ecosystems.

An opposite pattern has been noticed for $\mathrm{Mn}$ compared to $\mathrm{Hg}$. Indeed, $\mathrm{Mn}$ concentrations in oceanic pelagic communities were negatively correlated to fish size, trophic position and diet sources suggesting a biodilution process. Some studies also reported decreasing $\mathrm{Mn}$ concentrations with increasing trophic level in fish from various ecosystems (Cheng et al., 2013; Ikemoto et al., 2008). The biodilution of $\mathrm{Mn}$ in oceanic pelagic food web suggests a lack of the necessary regulatory and detoxification mechanisms for this essential element in lower trophic levels and smaller-sized species. However, the negative relationship between $\mathrm{Mn}$ and $\delta^{13} \mathrm{C}$ also raised the hypothesis of the influence of diet source on $\mathrm{Mn}$ exposure for the studied fish, with higher accumulation potential in pelagic-feeding compared to benthic-feeding species (Petkevich, 1967).

Apart from $\mathrm{Hg}$ and $\mathrm{Mn}$, few elements appeared influenced by biological processes. Only $\mathrm{Cd}$ and $\mathrm{Cu}$ tend to increase and decrease, respectively, with fish length, both metals being significantly correlated with $\mathrm{Hg}$. Finally, the lack of correlation between the other different elements in the same samples indicates that the possible detoxification process might operate independently for each metal in the selected oceanic pelagic fish. 


\subsection{Hg- Se antagonism in oceanic pelagic communities}

The mercury:selenium molar ratio (MHg:MSe) and Selenium Health Benefit Value (HBVSe) have been proposed as proxies to better appreciate Se-specific nutritional benefits in relation to $\mathrm{Hg}$ exposure risk (Kaneko and Ralston, 2007; Ralston et al., 2015). According to our results, Se was in molar excess of $\mathrm{Hg}$ in almost all species evaluated, indicating a general healthy profile of the fish analyzed. Only one specimen of wahoo from the 73 pelagic fish analysed for both $\mathrm{Hg}$ and Se displayed a slightly unbalanced $\mathrm{Hg}$ :Se molar ratio (1.01) and consequently negative Se-HBV (-0.89). Protective effects of Se against $\mathrm{Hg}$ bioaccumulation and toxicity have been demonstrated in a range of organisms (Belzile et al., 2006; Chen et al., 2001; Storelli et al., 2002) suggesting that a universal Se-Hg antagonism may exist. These protective effects, however, depend on the relative concentration and bioavailability of $\mathrm{Hg}$ and $\mathrm{Se}$, the sensitivity of the species and tissue considered, as well as, for a given species, the individual life history traits as shown in the present study and others (e.g., influence of age, growth, diet, habitat). Further investigations on $\mathrm{Hg}$ biomagnification and exposure risk assessment in organisms and food webs together with Se availability and other nutrients have thus to be considered in different ecosystems to improve our understanding on the variability of $\mathrm{Hg}$-Se interaction and its protective effects. Such research field is of primary importance for ecosystem and human health, and for the economy of countries such as the Republic of Seychelles which focus on a sustainable ocean-based development strategy.

\section{Acknowledgments}

The authors wish to thank the fishermen and observers onboard the EU purse-seiner Belouve and the Seychelles longliner Albacore for their help with fish sampling, in particular Elvis Hoareau and Emmanuel Chassot. We are also very grateful to Emmanuel Chassot for drawing the map and editing the manuscript. This study is part of the SEYFISH project co-funded by the Institute for Research and Development (IRD) and the Seychelles Fishing Authority (SFA). 


\section{References}

Agusa, T., Kunito, T., Yasunaga, G., Iwata, H., Subramanian, A., Ismail, A., Tanabe, S., 2005. Concentrations of trace elements in marine fish and its risk assessment in Malaysia. Mar. Pollut. Bull. 51, 896-911. doi:10.1016/j.marpolbul.2005.06.007

Amandé, M.J., Chassot, E., Chavance, P., Murua, H., Molina, A.D. de, Bez, N., 2012. Precision in bycatch estimates: the case of tuna purse-seine fisheries in the Indian Ocean. ICES J. Mar. Sci.

Araújo, C.V.M., Cedeño-Macias, L.A., 2016. Heavy metals in yellowfin tuna (Thunnus albacares) and common dolphinfish (Coryphaena hippurus) landed on the Ecuadorian coast. Sci. Total Environ. 541, 149-154. doi:10.1016/j.scitotenv.2015.09.090

Belzile, N., Chen, Y.-W., Gunn, J.M., Tong, J., Alarie, Y., Delonchamp, T., Lang, C.-Y., 2006. The effect of selenium on mercury assimilation by freshwater organisms. Can. J. Fish. Aquat. Sci. 63, 1-10. doi:10.1139/f05-202

Bodin, N., Budzinski, H., Le Ménach, K., Tapie, N., 2009. ASE extraction method for simultaneous carbon and nitrogen stable isotope analysis in soft tissues of aquatic organisms. Anal. Chim. Acta 643, 5460. doi:10.1016/j.aca.2009.03.048

Branco, V., Vale, C., Canário, J., Santos, M.N. dos, 2007. Mercury and selenium in blue shark (Prionace glauca, L. 1758) and swordfish (Xiphias gladius, L. 1758) from two areas of the Atlantic Ocean. Environ. Pollut. 150, 373-380.

Burton, M.L., Potts, J.C., Carr, D.R., Cooper, M., Lewis, J., 2015. Age, growth, and mortality of gray triggerfish (Balistes capriscus) from the southeastern United States. Fish. Bull. 113, 27-39. doi:10.7755/FB.113.1.3

Bustamante, P., González, A.F., Rocha, F., Miramand, P., Guerra, A., 2008. Metal and metalloid concentrations in the giant squid Architeuthis dux from Iberian waters. Mar. Environ. Res. 66, 278287. doi:10.1016/j.marenvres.2008.04.003 
Cai, Y., Rooker, J.R., Gill, G., 2006. Bioaccumulation of Mercury in Pelagic Fishes in NW Gulf of Mexico and its Relationship with Length, Location, Collection Year, and Trophic level, in: 57th Gulf and Caribbean Fisheries Institute. pp. 317-326.

Cai, Y., Rooker, J.R., Gill, G.A., Turner, J.P., 2007. Bioaccumulation of mercury in pelagic fishes from the northern Gulf of Mexico. Can. J. Fish. Aquat. Sci. 64, 458-469. doi:10.1139/f07-017

Chasapis, C.T., Loutsidou, A.C., Spiliopoulou, C.A., Stefanidou, M.E., 2012. Zinc and human health: an update. Arch. Toxicol. 86, 521-534.

Chen, Y.-W., Belzile, N., Gunn, J.M., 2001. Antagonistic effect of selenium on mercury assimilation by fish populations near Sudbury metal smelters? Limnol. Oceanogr. 46, 1814-1818. doi:10.4319/lo.2001.46.7.1814

Cheng, Z., Man, Y.B., Nie, X.P., Wong, M.H., 2013. Trophic relationships and health risk assessments of trace metals in the aquaculture pond ecosystem of Pearl River Delta, China. Chemosphere 90, 21422148. doi:10.1016/j.chemosphere.2012.11.017

Choy, C.A., Popp, B.N., Kaneko, J.J., Drazen, J.C., 2009. The influence of depth on mercury levels in pelagic fishes and their prey. Proc. Natl. Acad. Sci. 106, 13865-13869.

Chumchal, M.M., Drenner, R.W., Fry, B., Hambright, K.D., Newland, L.W., 2008. Habitat-Specific Differences in Mercury Concentration in a Top Predator from a Shallow Lake. Trans. Am. Fish. Soc. 137, 195208. doi:10.1577/t07-009.1

Codex Alimentarius Commission, 2011. Codex Committee on Contaminants in Foods (CCCF5_INF1). Accessed 21 March 2011, available at: http://www.fao.org/fao-who-codexalimentarius/meetingsreports/en/?y=2011\&mf=07.

Collette, B., Nauen, C., 1983. Scombrids of the world. An annotated and illustrated catalogue of tunas, mackerels, bonitos and related species known to date. FAO Species Cat. 2, 137.

Deshpande, A., Bhendigeri, S., Shirsekar, T., Dhaware, D., Khandekar, R.N., 2008. Analysis of heavy metals in marine fish from Mumbai Docks. Environ. Monit. Assess. 159, 493-500. doi:10.1007/s10661-0080645-3 
Eagles-Smith, C.A., Ackerman, J.T., Willacker, J.J., Tate, M.T., Lutz, M.A., Fleck, J.A., Stewart, A.R., Wiener, J.G., Evers, D.C., Lepak, J.M., Davis, J.A., Pritz, C.F., 2016. Spatial and temporal patterns of mercury concentrations in freshwater fish across the Western United States and Canada. Sci. Total Environ. in press. doi:10.1016/j.scitotenv.2016.03.229

EC, 2011. Commission regulation no.420/2011 of 29 April 2011 amending Regulation (EC) No 1881/2006 setting maximum levels for certain contaminants in foodstuffs (Text with EEA relevance).

EC, 2006. Commission regulation no.1881/2006 of 19 December 2006 setting maximum levels for certain contaminants in foodstuffs (text with EEA relevance).

Farley, J.H., Clear, N.P., Leroy, B., Davis, T.L., McPherson, G., 2006. Age, growth and preliminary estimates of maturity of bigeye tuna, Thunnus obesus, in the Australian region. Mar. Freshw. Res. 57, 713724.

Flores-Mateo, G., Navas-Acien, A., Pastor-Barriuso, R., Guallar, E., 2006. Selenium and coronary heart disease: a meta-analysis. Am J Clin Nutr 84, 762-773.

Goldhaber, S.B., 2003. Trace element risk assessment: essentiality vs. toxicity. Regul. Toxicol. Pharmacol. $38,232-242$

Goutte, A., Cherel, Y., Churlaud, C., Ponthus, J.-P., Massé, G., Bustamante, P., 2015. Trace elements in Antarctic fish species and the influence of foraging habitats and dietary habits on mercury levels. Sci. Total Environ. 538, 743-749. doi:10.1016/j.scitotenv.2015.08.103

Greenwald, P., Anderson, D., Nelson, S.A., Taylor, P.R., 2007. Clinical trials of vitamin and mineral supplements for cancer prevention. Am J Clin Nutr 85, 314-317.

Ikemoto, T., Tu, N.P.C., Watanabe, M.X., Okuda, N., Omori, K., Tanabe, S., Tuyen, B.C., Takeuchi, I., 2008. Analysis of biomagnification of persistent organic pollutants in the aquatic food web of the Mekong Delta, South Vietnam using stable carbon and nitrogen isotopes. Chemosphere 72, 104-114.

IOTC, 2010. Recommendation 10/13 on the implementation of a ban on discards of skipjack tuna, yellwfin tuna, bigeye tuna and non-targeted species caught by purse-seiners.

Iwasaki, Y., 1995. Age and growth of rainbow runner. J. Sch. Mar. Sci. Technol. Tokai Univ. 39, 101-109. 
Jinadasa, B.K.K.K., Ahmad, S.B.N., Edirisinghe, E.M.R.K.B., Wicramasinghe, I., 2014a. Mercury Content in Yellowfin Tuna (Thunnus albacares) and Swordfish (Xiphias gladius) and Estimation of Mercury Intake. J. Food Secur. 2, 23-26. doi:10.12691/jfs-2-1-3

Jinadasa, B.K.K.K., Edirisinghe, E.M.R.K.B., Wickramasinghe, I., 2014b. Total mercury, cadmium and lead levels in main export fish of Sri Lanka. Food Addit. Contam. Part B 7, 309-314. doi:10.1080/19393210.2014.938131

Kaneko, J.J., Ralston, N.V.C., 2007. Selenium and Mercury in Pelagic Fish in the Central North Pacific Near Hawaii. Biol. Trace Elem. Res. 119, 242-254. doi:10.1007/s12011-007-8004-8

Khandaker, M.U., Asaduzzaman, K., Nawi, S.M., Usman, A.R., Amin, Y.M., Daar, E., Bradley, D.A., Ahmed, H., Okhunov, A.A., 2015. Assessment of Radiation and Heavy Metals Risk due to the Dietary Intake of Marine Fishes (Rastrelliger kanagurta) from the Straits of Malacca. PLoS ONE 10, e0128790. doi:10.1371/journal.pone.0128790

Kojadinovic, J., Potier, M., Le Corre, M., Cosson, R.P., Bustamante, P., 2007. Bioaccumulation of trace elements in pelagic fish from the Western Indian Ocean. Environ. Pollut. 146, 548-566.

Kojadinovic, J., Potier, M., Le Corre, M., Cosson, R.P., Bustamante, P., 2006. Mercury content in commercial pelagic fish and its risk assessment in the Western Indian Ocean. Sci. Total Environ. 366, 688-700.

Luckhurst, B.E., Prince, E.D., Llopiz, J.K., Snodgrass, D., Brothers, E.B., 2006. Evidence Of blue marlin (Makaira nigricans) spawning in Bermuda waters and elevated mercury levels in large specimens. Bull. Mar. Sci. 79, 691-704.

MAFF, 1995. Monitoring and surveillance of non-radioactive contaminants in the aquatic environment and activities regulating the disposal of wastes at sea. Directorate of Fisheries Research, Lowestoft.

Magalhães, M.C., Costa, V., Menezes, G.M., Pinho, M.R., Santos, R.S., Monteiro, L.R., 2007. Intra- and interspecific variability in total and methylmercury bioaccumulation by eight marine fish species from the Azores. Mar. Pollut. Bull. 54, 1654-1662. doi:10.1016/j.marpolbul.2007.07.006

Mendez, E., Giudice, H., Pereira, A., Inocente, G., Medina, D., 2001. Total Mercury Content - Fish Weight Relationship in Swordfish (Xiphias gladius) Caught in the Southwest Atlantic Ocean. J. Food Compos. Anal. 14, 453-460. 
Monnereau, I., Failler, P., 2014. Unlocking the full potential of the blue economy: Are African Small Island Developing States ready to embrace the opportunities? United Nations Economic Commission for Africa - Technical report.

Monteiro, L.R., Lopes, H.D., 1990. Mercury content of swordfish, Xiphias gladius, in relation to length, weight, age, and sex. Mar. Pollut. Bull. 21, 293-296. doi:10.1016/0025-326X(90)90593-W

Mukherjee, D.P., Kumar, B., 2011. Assessment of Arsenic, Cadmium and Mercury Level in Commonly Consumed Coastal Fishes from Bay of Bengal, India. Food Sci. Qual. Manag. 2, 19-30.

NAS, 2002. Dietary Reference Intakes for Vitamin A, Vitamin K, Arsenic, Boron, Chromium, Copper, lodine, Iron, Molybdenum, Nickel, Silicon, Vanadium, and Zinc. National Academy Press, Washington, DC.

Park, K., Mozaffarian, D., 2010. Omega-3 Fatty Acids, Mercury, and Selenium in Fish and the Risk of Cardiovascular Diseases. Curr. Atheroscler. Rep. 12, 414-422. doi:10.1007/s11883-010-0138-z

Petkevich, T.A., 1967. Elemental composition of bony tissues of plankton-feeding and benthos-feeding fish from the Northwest part of the Black Sea. Dop Akad Nauk Ukr RSR Ser B 29, 142-146.

Plessi, M., Bertelli, D., Monzani, A., 2001. Mercury and Selenium Content in Selected Seafood. J. Food Compos. Anal. 14, 461-467. doi:10.1006/jfca.2001.1003

Ralston, N.V.C., Ralston, C.R., Raymond, L.J., 2015. Selenium Health Benefit Values: Updated Criteria for Mercury Risk Assessments. Biol. Trace Elem. Res. 1-8. doi:10.1007/s12011-015-0516-z

Rodrigues, M.V., Yamatogi, R.S., Sudano, M.J., Galvao, J.A., de Pérez, A.C.A., Biondi, G.F., 2013. Mercury Concentrations in South Atlantic Swordfish, Xiphias gladius, Caught off the Coast of Brazil. Bull. Environ. Contam. Toxicol. 90, 697-701.

Shultz, C.D., Crear, D., 1976. The distribution of total and organic mercury in seven tissues of the Pacific blue marlin, Makaira nigricans. Pac. Sci. 30, 101-107.

Shultz, C.D., Ito, B.M., 1978. Mercury and selenium in blue marlin, Makaira nigricans, from the Hawaiian Islands. Fish. Bull. 76, 872-878.

Storelli, M.M., Giacominelli-Stuffler, R., Marcotrigiano, G.O., 2002. Total and methylmercury residues in cartilaginous fish from Mediterranean Sea. Mar. Pollut. Bull. 44, 1354-1358. doi:10.1016/S0025$326 \times(02) 00223-0$ 
Storelli, M.M., Giacominelli-Stuffler, R., Storelli, A., Marcotrigiano, G.O., 2005. Accumulation of mercury, cadmium, lead and arsenic in swordfish and bluefin tuna from the Mediterranean Sea: A comparative study. Mar. Pollut. Bull. 50, 1004-1007.

Wells, R.J.D., Kohin, S., Teo, S.L.H., Snodgrass, O.E., Uosaki, K., 2013. Age and growth of North Pacific albacore (Thunnus alalunga): Implications for stock assessment. Fish. Res. 147, 55-62. doi:10.1016/j.fishres.2013.05.001

Yamashita, Y., Amlund, H., Suzuki, T., Hara, T., Hossain, M.A., Yabu, T., Touhata, K., Yamashita, M., 2011. Selenoneine, total selenium, and total mercury content in the muscle of fishes. Fish. Sci. 77, 679686. doi:10.1007/s12562-011-0360-9 


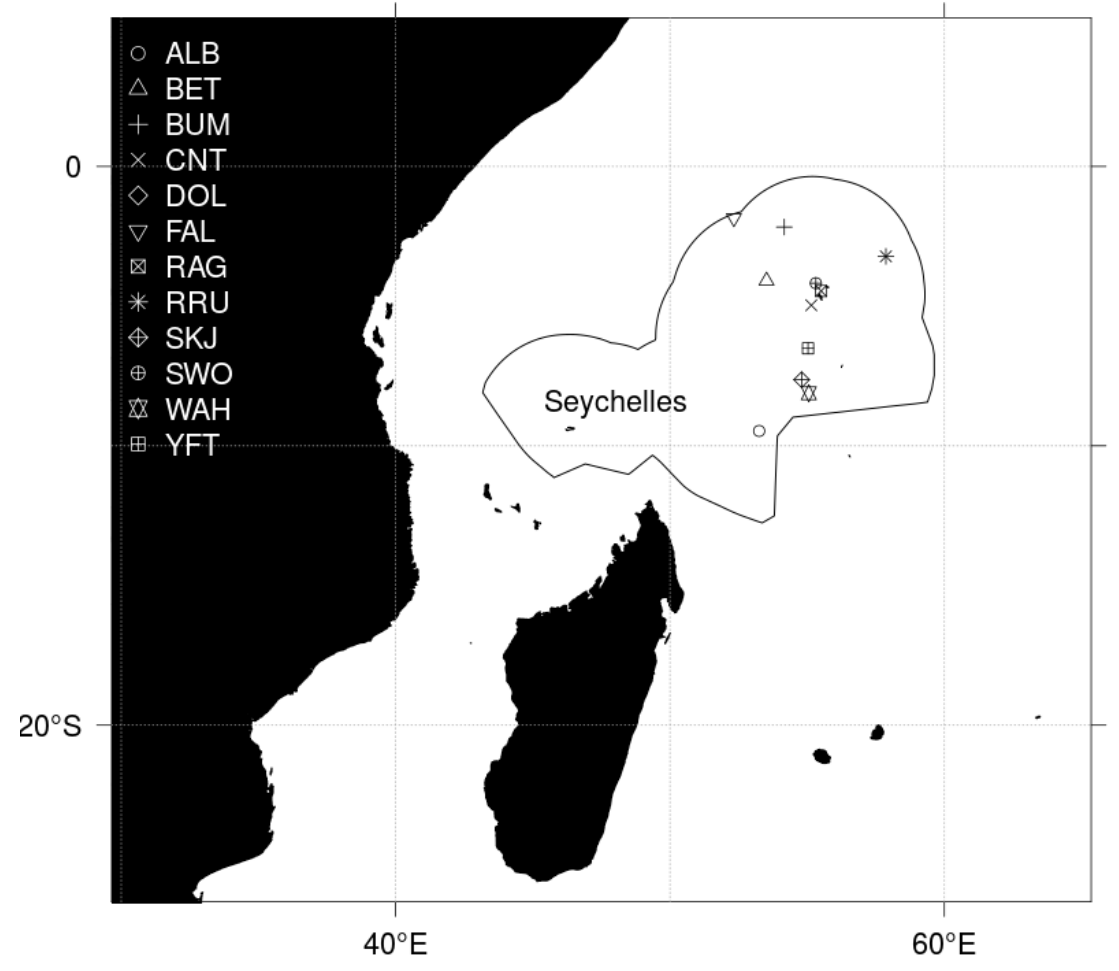

Fig. 1. Mean location of the oceanic pelagic fish species caught by industrial and semi-industrial fishing vessels in the western Indian Ocean during the northeast monsoon season (November 2014 - February 2015). The limit of the Exclusive Economic Zone of the Republic of Seychelles is indicated with black solid line. 


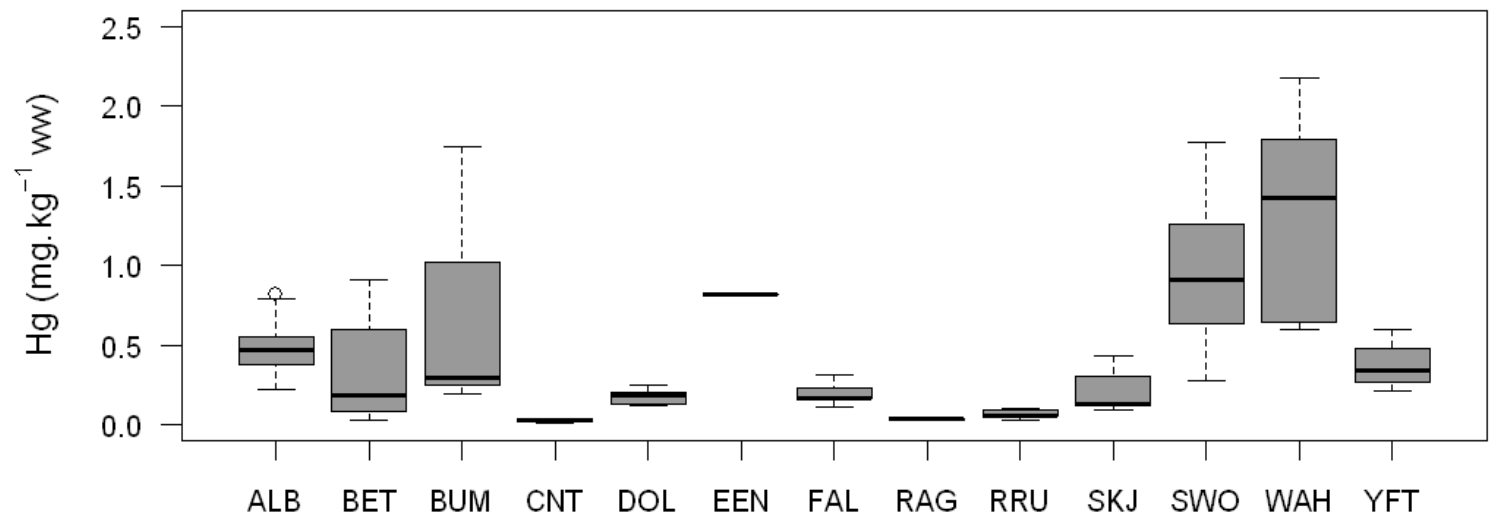

Fig. 2. Boxplot of Hg levels (ppm ww) in the muscle of 13 oceanic pelagic fish species caught in the westerncentral Indian Ocean. ALB = Albacore tuna, BET = Bigeye tuna, BUM = Blue marlin, $\mathrm{CNT}=$ Rough triggerfish, $\mathrm{DOL}=$ Dolphinfish, $\mathrm{EEN}=$ Giant grouper, $\mathrm{FAL}=$ Silky shark, $\mathrm{RAG}=$ Indian mackerel, $\mathrm{RRU}=$ Rainbow runner, SKJ $=$ Skipjack tuna, SWO $=$ Swordfish, $\mathrm{WAH}=$ Wahoo, YFT $=$ Yellowfin tuna. Letters indicate significant differences between species. 

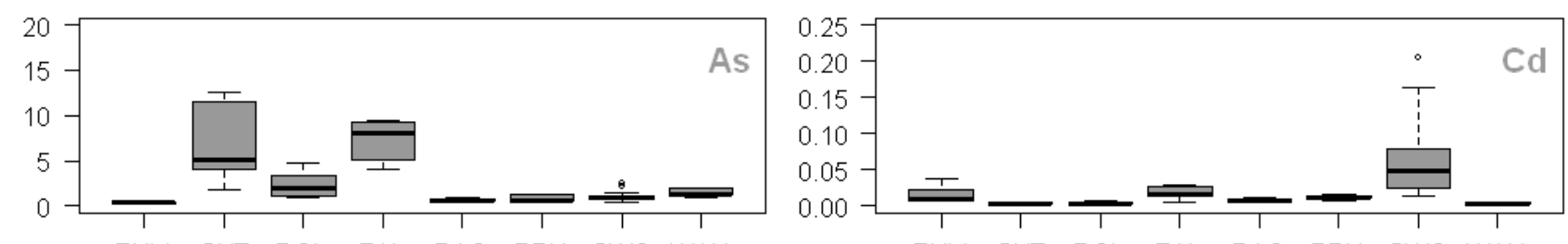

BUM CNT DOL FAL RAG RRU SWO WAH
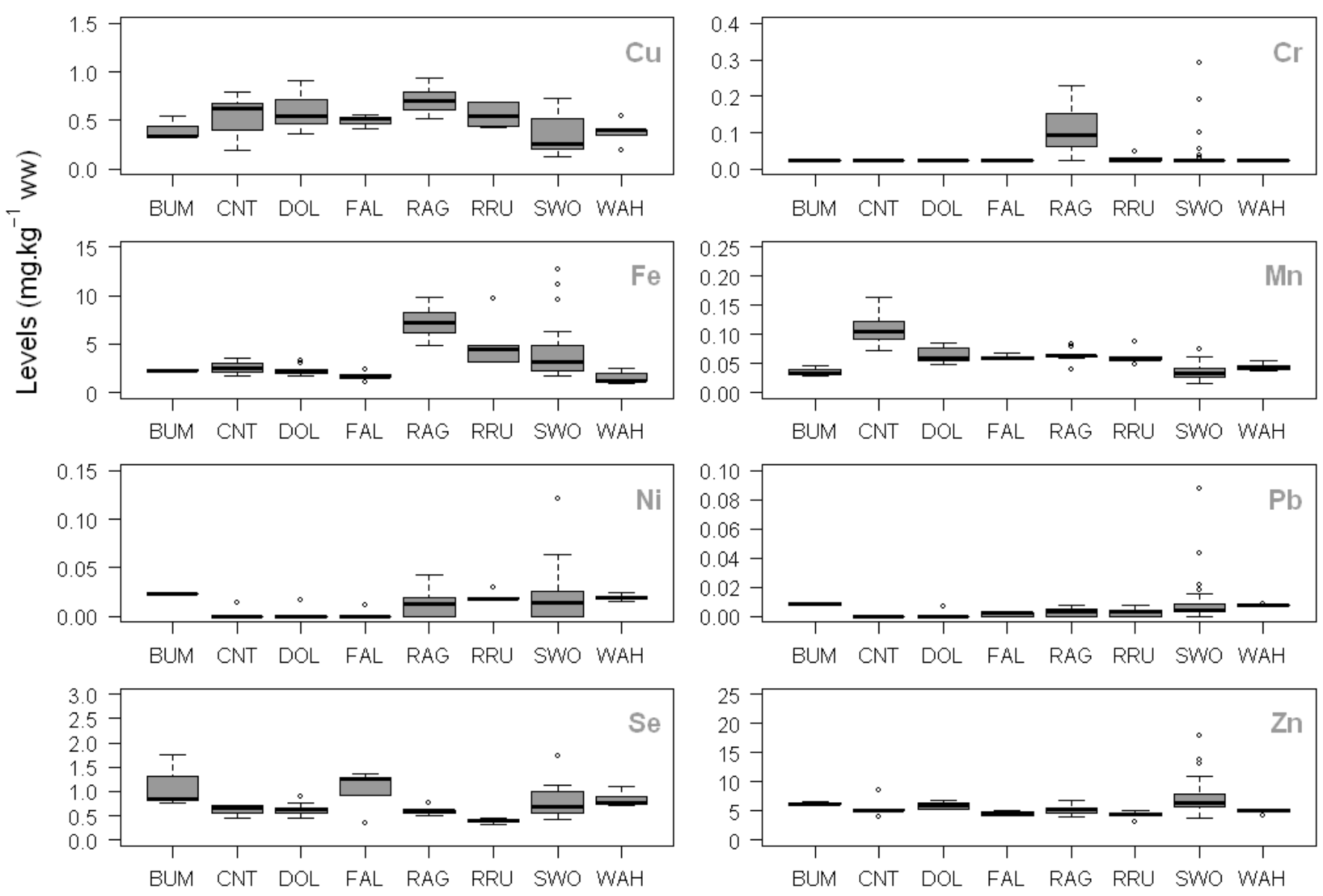

Fig. 3. Boxplots of trace element levels (ppm ww) in the muscle of eight oceanic pelagic fish species caught in the western-central Indian Ocean. BUM = Blue marlin, CNT = Rough triggerfish, DOL $=$ Dolphinfish, $F A L=$ Silky shark, RAG $=$ Indian mackerel, RRU $=$ Rainbow runner, SWO $=$ Swordfish, $W A H=$ Wahoo. Letters indicate significant differences between species. 

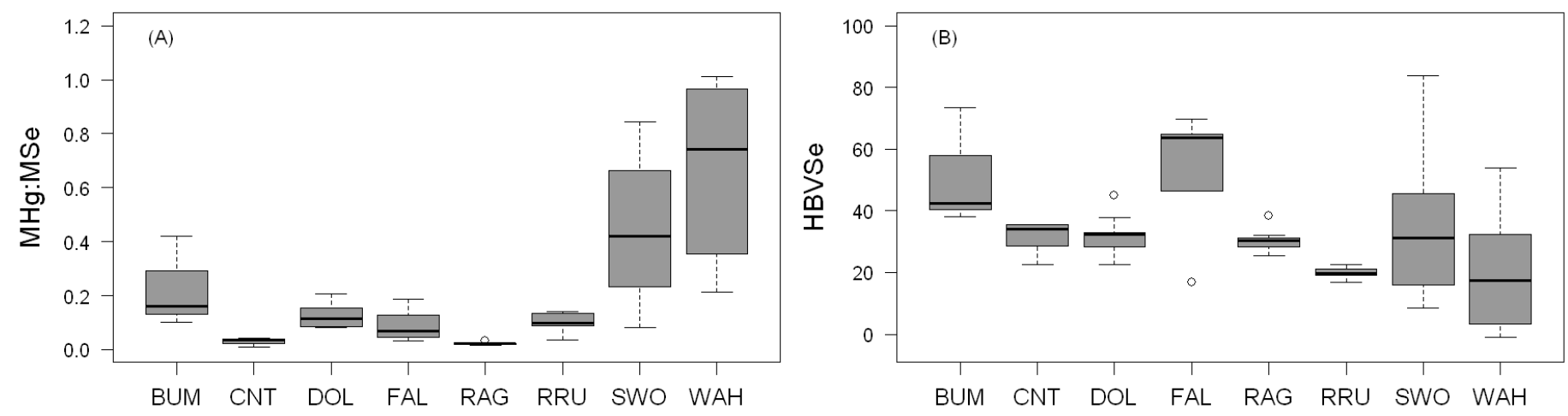

Fig. 4. Boxplots of (A) Hg:Se molar ratios (MHg:MSe) and (B) Selenium Health Benefit Values (HBVSe) in the muscle of eight oceanic pelagic fish species caught in the western-central Indian Ocean. BUM = Blue marlin, $\mathrm{CNT}=$ Rough triggerfish, $\mathrm{DOL}=$ Dolphinfish, $\mathrm{FAL}=$ Silky shark, $\mathrm{RAG}=$ Indian mackerel, RRU = Rainbow runner, $\mathrm{SWO}=$ Swordfish, $\mathrm{WAH}=$ Wahoo. Letters indicate significant differences between species . 
Table 1. Method quantification limits (MQL; $\mathrm{mg} \cdot \mathrm{kg}^{-1} \mathrm{dw}$ ), and recovery rate (\%) for trace metal concentrations (mg.kg-1 dw) in the certified reference materials NRCC-DOLT-4 and NRCC-TORT-3 $(n=17)$. Data are given as mean \pm standard deviation. ICP-OES = inductively coupled plasma atomic emission spectrometry; ICP-MS = inductively coupled plasma mass spectrometry; nd = not determined.

\begin{tabular}{llllcccc}
\hline \multirow{2}{*}{ Symbol } & \multirow{2}{*}{ Element } & \multirow{2}{*}{ Method } & \multirow{2}{*}{ MQL } & \multicolumn{2}{c}{ DOLT4 } & \multicolumn{2}{c}{ TORT3 } \\
\cline { 5 - 7 } & & & & Expected value & Recovery & Expected value & Recovery \\
\hline $\mathrm{Ag}$ & Silver & ICP-MS & 0.0100 & $0.97 \pm 0.11$ & $81.3 \pm 0.0$ & nd & nd \\
$\mathrm{As}$ & Arsenic & ICP-OES & 0.8200 & $9.66 \pm 0.62$ & $96.3 \pm 0.0$ & $59.5 \pm 3.8$ & $114.6 \pm 0.1$ \\
$\mathrm{Cd}$ & Cadmium & ICP-MS & 0.0100 & $24.3 \pm 0.8$ & $98.8 \pm 0.1$ & $42.3 \pm 1.8$ & $96.7 \pm 0.0$ \\
$\mathrm{Co}$ & Cobalt & ICP-MS & 0.0100 & nd & nd & 1.06 & $96.9 \pm 0.1$ \\
$\mathrm{Cu}$ & Copper & ICP-OES & 0.0800 & $31.2 \pm 1.1$ & $99.6 \pm 0.1$ & $497 \pm 22$ & $90.9 \pm 0.0$ \\
$\mathrm{Cr}$ & Chromium & ICP-OES & 0.0900 & nd & nd & $1.95 \pm 0.24$ & $91.6 \pm 0.1$ \\
$\mathrm{Fe}$ & Iron & ICP-OES & 3.9700 & $1833 \pm 75$ & $91.6 \pm 0.0$ & $179 \pm 8$ & $90.1 \pm 0.0$ \\
$\mathrm{Mn}$ & Manganese & ICP-OES & 0.0100 & nd & nd & $15.6 \pm 1$ & $90.1 \pm 0.0$ \\
$\mathrm{Ni}$ & Nickel & ICP-OES & 0.0010 & $1.33 \pm 0.12$ & $97.5 \pm 0.1$ & $5.3 \pm 0.24$ & $93.4 \pm 0.1$ \\
$\mathrm{~Pb}$ & Lead & ICP-MS & 0.0001 & $0.16 \pm 0.04$ & $82.8 \pm 0.1$ & $0.225 \pm 0.018$ & $80.2 \pm 0.1$ \\
$\mathrm{Se}$ & Selenuim & ICP-MS & 0.1000 & $2.58 \pm 0.22$ & $101.9 \pm 0.1$ & $10.9 \pm 1$ & $102.5 \pm 0.1$ \\
$\mathrm{~V}$ & Vanadium & ICP-MS & 0.9400 & nd & nd & $9.1 \pm 0.4$ & $91.6 \pm 0.0$ \\
$\mathrm{Zn}$ & Zinc & ICP-OES & 0.3600 & $8.3 \pm 1.3$ & $105.1 \pm 0.0$ & $136 \pm 6$ & $100.5 \pm 0.0$ \\
\hline
\end{tabular}


Table 2. Mean \pm standard deviation of fish size $(\mathrm{cm})$, and water content (\%), fat content (TLC, \%), nitrogen and carbon isotope values $\left(\delta^{15} \mathrm{~N}\right.$ and $\delta^{13} \mathrm{C}, \%$ ), and mercury levels on a wet weight basis (ppm ww) in the white muscle of 13 oceanic pelagic fish species caught in the western-central Indian Ocean. $n=$ Number of fish; Length = Size of the fish in $\mathrm{cm}$ corresponding to low jaw fork length for blue marlin and swordfish and to fork length for others.

\begin{tabular}{|c|c|c|c|c|c|c|c|c|}
\hline Common name & Scientific name & $\mathbf{N}$ & $\begin{array}{l}\text { Length } \\
(\mathrm{cm})\end{array}$ & $\begin{array}{c}\text { Water } \\
(\%)\end{array}$ & $\begin{array}{c}\text { TLC } \\
\text { (\%dw) }\end{array}$ & $\begin{array}{l}\delta^{13} \mathrm{C} \\
(\% \circ)\end{array}$ & $\begin{array}{l}\delta^{15} \mathrm{~N} \\
(\% \circ)\end{array}$ & $\begin{array}{c}\mathrm{Hg} \\
(\mathrm{ppm} w w)\end{array}$ \\
\hline Rough triggerfish & anthidermis & 5 & $32 \pm 4$ & $84.3 \pm 2.1$ & $5.0 \pm 0.7$ & $-17.7 \pm 0.2$ & $11.6 \pm 0.3$ & $0.028 \pm 0.013$ \\
\hline Indial & Rastrelliger kanagurta & 10 & $26 \pm 1$ & $71.9 \pm 1.6$ & $13.9 \pm 9.6$ & $-17.3 \pm 0.2$ & $12.0 \pm 0.3$ & 0.03 \\
\hline Rainbow runner & Elagatis bipinnulata & 5 & $75 \pm 16$ & $82.5 \pm 2.3$ & $6.4 \pm 2.2$ & $-17.0 \pm 0.2$ & $12.6 \pm 0.2$ & $0.069 \pm 0.031$ \\
\hline Dolphinfish & Coryphaena hippurus & 10 & $99 \pm 7$ & $77.4 \pm 2.8$ & $1.9 \pm 0.7$ & $-16.6 \pm 0.1$ & $13.5 \pm 0.4$ & $0.177 \pm 0.043$ \\
\hline Silky & Carcharhinus falciformis & 5 & $80 \pm 11$ & $73.9 \pm 2.2$ & $6.3 \pm 1.1$ & $-16.5 \pm 0.1$ & $13.3 \pm 0.5$ & .076 \\
\hline $\mathrm{s}$ & Kats & 13 & $57 \pm 10$ & 71 & 1.5 & -16 & $11.5 \pm 0.6$ & 0.2 \\
\hline & 1 & 5 & 13 & & & & $12.3 \pm 0.5$ & 0.37 \\
\hline Big & The & 27 & & & & 0.3 & 0.7 & 0.33 \\
\hline & Thi & 30 & 9 & 69 & 1.5 & & 12.5 & 0.4 \\
\hline Giar & Epine & 1 & 1 & 74.1 & 5.4 & -1 & 14 & $0 . \varepsilon$ \\
\hline Blue & Maka & 3 & $19+$ & $76.8 \pm$ & 2.9 & -16 & $13.8 \pm 0.1$ & 0.747 \\
\hline Swo & phias gladius & 33 & $150 \pm 31$ & $67.1 \pm 8.7$ & $26.2 \pm 18.9$ & $-16.2 \pm 0.2$ & $14.8 \pm 0.4$ & $0.987 \pm 0.446$ \\
\hline Wahoo & Acanthocybium solandri & 5 & $106 \pm 9$ & $75.2 \pm 2.1$ & $3.1 \pm 0.2$ & $-16.2 \pm 0.2$ & $14.1 \pm 0.5$ & $1.329 \pm 0.695$ \\
\hline
\end{tabular}


Table 3. Spearman correlation matrix between trace element concentrations, fish size (length), and isotopic values $\left(\delta^{13} \mathrm{C}\right.$ and $\left.\delta^{15} \mathrm{~N}\right)$ in oceanic pelagic fish caught in the western-central Indian Ocean. Values with absolute rho coefficient $>0.5$ are in bold. ${ }^{* *} p<0.01 ;{ }^{* * *} p<0.001$.

\begin{tabular}{|c|c|c|c|c|c|c|c|c|c|c|c|c|c|}
\hline & length & $\delta^{13} \mathrm{C}$ & $\delta^{15} \mathrm{~N}$ & $\mathrm{Hg}$ & As & $\mathrm{Cd}$ & $\mathrm{Cr}$ & $\mathrm{Cu}$ & $\mathrm{Fe}$ & $\mathrm{Mn}$ & $\mathrm{Ni}$ & $\mathrm{Pb}$ & $\mathrm{Se}$ \\
\hline $\mathrm{Hg}$ & $0.72^{* * *}$ & $0.43^{* * *}$ & $0.52^{* * *}$ & & & & & & & & & & \\
\hline As & $-0.34^{* *}$ & -0.23 & -0.22 & $-0.30^{* *}$ & & & & & & & & & \\
\hline $\mathrm{Cd}$ & $0.58^{* * *}$ & 0.01 & -0.01 & $0.60^{* * *}$ & -0.23 & & & & & & & & \\
\hline $\mathrm{Cr}$ & -0.15 & -0.34 & -0.40 & 0.01 & -0.18 & $0.33^{* *}$ & & & & & & & \\
\hline $\mathrm{Cu}$ & $-0.66^{* * *}$ & -0.39 & $-0.46^{* *}$ & $-0.59^{* * *}$ & 0.15 & $-0.47^{* * *}$ & 0.11 & & & & & & \\
\hline $\mathrm{Fe}$ & -0.17 & $-0.49^{* *}$ & $-0.54^{* * *}$ & -0.04 & -0.29 & 0.23 & $0.46^{* * *}$ & 0.24 & & & & & \\
\hline $\mathrm{Mn}$ & $-0.67^{* * *}$ & $-0.67^{* * *}$ & $-0.63^{* * *}$ & $-0.52^{* * *}$ & $0.44^{* * *}$ & $-0.35^{* *}$ & 0.13 & $0.48^{* * *}$ & 0.21 & & & & \\
\hline $\mathrm{Ni}$ & 0.24 & 0.09 & 0.02 & 0.24 & -0.25 & $0.49^{* * *}$ & $0.45^{* * *}$ & -0.06 & $0.43^{* * *}$ & -0.05 & & & \\
\hline $\mathrm{Pb}$ & $0.32^{* *}$ & $0.46^{* *}$ & 0.39 & $0.36^{* *}$ & -0.19 & $0.40^{* * *}$ & 0.10 & -0.12 & $0.49^{* * *}$ & -0.21 & $0.49^{* * *}$ & & \\
\hline Se & 0.21 & 0.33 & 0.37 & 0.26 & 0.08 & 0.10 & -0.17 & -0.04 & 0.02 & -0.04 & 0.07 & 0.17 & \\
\hline $\mathrm{Zn}$ & $0.37^{* *}$ & 0.06 & 0.00 & 0.25 & -0.19 & $0.43^{* * *}$ & 0.04 & -0.24 & 0.20 & -0.14 & 0.29 & 0.17 & 0.15 \\
\hline
\end{tabular}




\section{Supplementary material}

Trace elements in oceanic pelagic communities in the western-central Indian Ocean

Nathalie Bodin ${ }^{1,2}$, Dora Lesperance ${ }^{2}$, Rona Albert ${ }^{2}$, Stephanie Hollanda ${ }^{2}$, Philippe Michaud ${ }^{3}$, Maxime Degroote $^{1}$, Carine Churlaud ${ }^{4}$, Paco Bustamante ${ }^{4}$

${ }^{1}$ Institute for Research and Development (IRD), UMR MARine Biodiversity Exploitation and Conservation (MARBEC), Fishing Port, Victoria, Mahé Island, Republic of Seychelles

2 Seychelles Fishing Authority (SFA), Fishing Port, Victoria, Mahé Island, Republic of Seychelles

${ }^{3}$ Ministry of Finance, Trade and the Blue Economy, Victoria, Mahé Island, Republic of Seychelles

${ }^{4}$ LIENSs, UMR 7266, CNRS-Université de La Rochelle, 2 rue Olympe de Gouges, F-17000 La Rochelle, France 

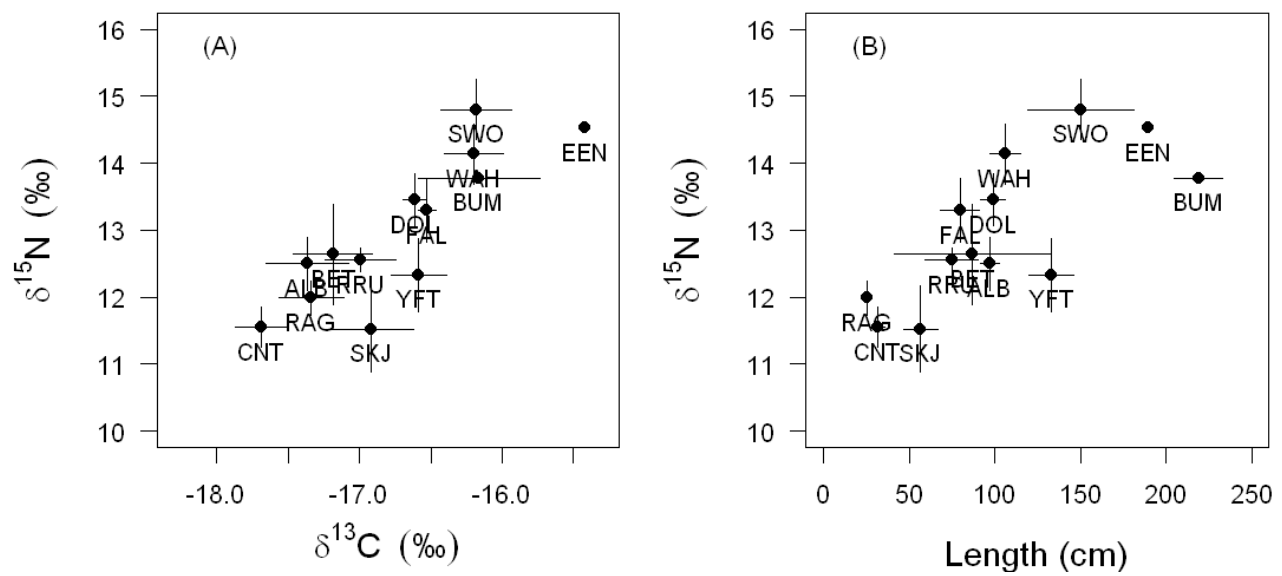

Fig. S1. Plots of meantstandard deviation of (A) carbon and nitrogen stable isotope ratios $\left(\delta^{13} \mathrm{C}\right.$ and $\left.\delta^{15} \mathrm{~N}\right)$, and (B) fish size and $\delta^{15} \mathrm{~N}$ for oceanic pelagic fish species caught in the western-central Indian Ocean. ALB = Albacore tuna, $\mathrm{BET}=$ Bigeye tuna, $\mathrm{BUM}=$ Blue marlin, $\mathrm{CNT}=$ Rough triggerfish, $\mathrm{DOL}=$ Dolphinfish, $\mathrm{EEN}=$ Giant grouper, FAL = Silky shark, RAG = Indian mackerel, RRU = Rainbow runner, SKJ = Skipjack tuna, SWO = Swordfish, $\mathrm{WAH}=$ Wahoo, $\mathrm{YFT}=$ Yellowfin tuna . 



Fig. S2. Plots of significant relationships between $(A)$ nitrogen stable isotope values $\left(\delta^{15} N\right)$ and $\log$ transformed Hg levels, (B) $\delta^{15} \mathrm{~N}$ and log-transformed Fe levels, (C) $\delta^{15} \mathrm{~N}$ and log-transformed Mn levels, (D) fish size (length, $\mathrm{cm}$ ) and log-transformed Cu levels, and (E) fish size and log-transformed Cu levels, for oceanic pelagic fish species caught in the western-central Indian Ocean. ALB = Albacore tuna, BET = Bigeye tuna, $\mathrm{BUM}=$ Blue marlin, $\mathrm{CNT}=$ Rough triggerfish, $\mathrm{DOL}=$ Dolphinfish, EEN = Giant grouper, $\mathrm{FAL}=$ Silky shark, RAG = Indian mackerel, $\mathrm{RRU}=$ Rainbow runner, $\mathrm{SKJ}=$ Skipjack tuna, $\mathrm{SWO}=$ Swordfish, $\mathrm{WAH}=$ Wahoo, YFT = Yellowfin tuna. 


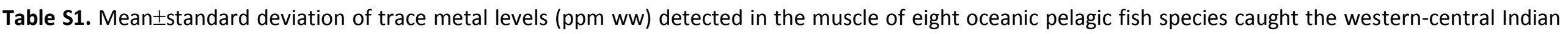
Ocean. Kruskal-Wallis results (statistic $\mathrm{H}$ and $\mathrm{p}$-value) of tests of difference in elements' content between species are also given.

\begin{tabular}{|c|c|c|c|c|c|c|c|c|c|c|}
\hline Common name & As & Cd & $\mathrm{Cr}$ & $\mathrm{Cu}$ & $\mathrm{Fe}$ & $\mathrm{Mn}$ & $\mathbf{N i}$ & $\mathrm{Pb}$ & Se & $\mathrm{Zn}$ \\
\hline Blue marlin & $0.316 \pm 0.037$ & $0.018 \pm 0.017$ & $0.025 \pm 0.000$ & $0.410 \pm 0.120$ & $2.286 \pm 0.112$ & $0.036 \pm 0.009$ & $0.023 \pm 0.001$ & $0.009 \pm 0.001$ & $1.126 \pm 0.550$ & $6.213 \pm 0.301$ \\
\hline Rough triggerfish & $7.009 \pm 4.769$ & $0.003 \pm 0.001$ & $0.025 \pm 0.000$ & $0.538 \pm 0.240$ & $2.587 \pm 0.738$ & $0.111 \pm 0.034$ & $0.003 \pm 0.006$ & $0.000 \pm 0.000$ & $0.617 \pm 0.111$ & $5.609 \pm 1.744$ \\
\hline Dolphinfish & $2.258 \pm 1.280$ & $0.004 \pm 0.001$ & $0.025 \pm 0.000$ & $0.580 \pm 0.169$ & $2.298 \pm 0.511$ & $0.064 \pm 0.012$ & $0.002 \pm 0.005$ & $0.001 \pm 0.002$ & $0.647 \pm 0.116$ & $5.853 \pm 0.601$ \\
\hline Silky shark & $7.191 \pm 2.468$ & $0.017 \pm 0.009$ & $0.025 \pm 0.000$ & $0.500 \pm 0.056$ & $1.685 \pm 0.514$ & $0.060 \pm 0.004$ & $0.002 \pm 0.005$ & $0.002 \pm 0.002$ & $1.040 \pm 0.423$ & $4.558 \pm 0.398$ \\
\hline Indian mackerel & $0.648 \pm 0.159$ & $0.008 \pm 0.002$ & $0.106 \pm 0.066$ & $0.705 \pm 0.136$ & $7.095 \pm 1.546$ & $0.064 \pm 0.011$ & $0.015 \pm 0.015$ & $0.003 \pm 0.003$ & $0.600 \pm 0.070$ & $5.253 \pm 0.831$ \\
\hline Rainbow runner & $0.838 \pm 0.378$ & $0.012 \pm 0.003$ & $0.031 \pm 0.009$ & $0.558 \pm 0.127$ & $5.100 \pm 2.691$ & $0.063 \pm 0.014$ & $0.021 \pm 0.005$ & $0.003 \pm 0.003$ & $0.395 \pm 0.043$ & $4.311 \pm 0.712$ \\
\hline Swordfish & $0.939 \pm 0.468$ & $0.059 \pm 0.048$ & $0.044 \pm 0.058$ & $0.342 \pm 0.175$ & $4.124 \pm 2.782$ & $0.036 \pm 0.014$ & $0.020 \pm 0.025$ & $0.010 \pm 0.017$ & $0.763 \pm 0.284$ & $7.480 \pm 3.128$ \\
\hline Wahoo & $1.503 \pm 0.449$ & $0.004 \pm 0.001$ & $0.025 \pm 0.000$ & $0.379 \pm 0.124$ & $1.586 \pm 0.648$ & $0.044 \pm 0.007$ & $0.019 \pm 0.003$ & $0.008 \pm 0.001$ & $0.842 \pm 0.170$ & $4.990 \pm 0.508$ \\
\hline $\mathrm{H}$ & 47.40 & 58.44 & 34.70 & 29.41 & 38.79 & 47.22 & 26.16 & 30.85 & 25.64 & 30.77 \\
\hline$p$-value & 4.67E-08 & $3.09 \mathrm{E}-10$ & 1.27E-05 & $1.22 \mathrm{E}-04$ & $2.15 \mathrm{E}-06$ & $5.05 \mathrm{E}-08$ & 4.72E-04 & $6.61 \mathrm{E}-05$ & 5.84E-04 & $6.86 \mathrm{E}-05$ \\
\hline
\end{tabular}




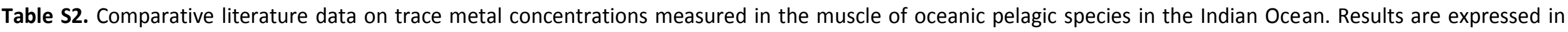
ppm on a wet weight ( $w w$ ) or dry weight ( $d w)$ basis, as mean \pm standard deviation or minimum-maximum values.

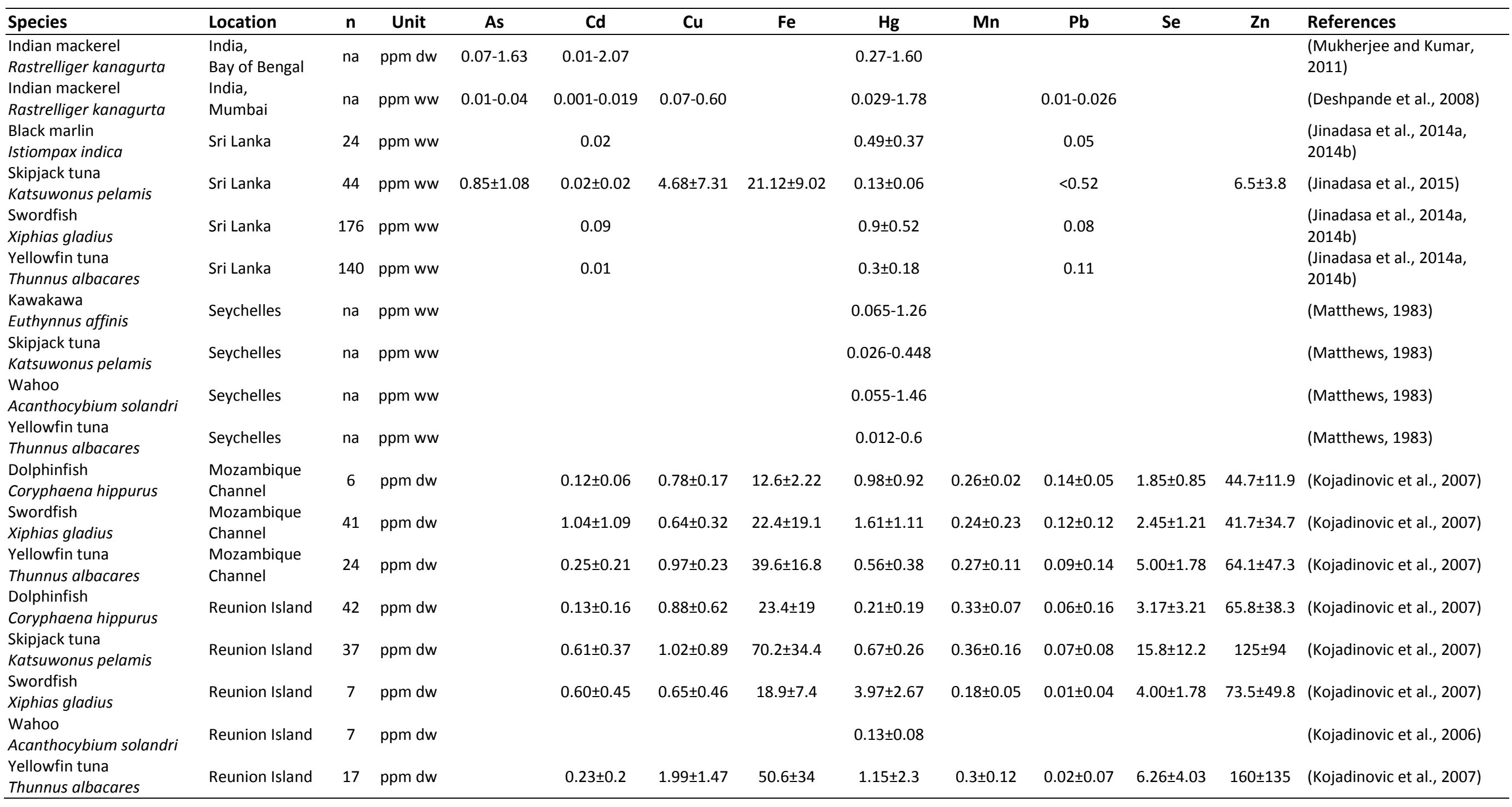




\section{References related to Table S2:}

Deshpande, A., Bhendigeri, S., Shirsekar, T., Dhaware, D., Khandekar, R.N., 2008. Analysis of heavy metals in marine fish from Mumbai Docks. Environ. Monit. Assess. 159, 493-500. doi:10.1007/s10661-0080645-3

Jinadasa, B.K.K.K., Ahmad, S.B.N., Edirisinghe, E.M.R.K.B., Wicramasinghe, I., 2014a. Mercury Content in Yellowfin Tuna (Thunnus albacares) and Swordfish (Xiphias gladius) and Estimation of Mercury Intake. J. Food Secur. 2, 23-26. doi:10.12691/jfs-2-1-3

Jinadasa, B.K.K.K., Edirisinghe, E.M.R.K.B., Wickramasinghe, I., 2014b. Total mercury, cadmium and lead levels in main export fish of Sri Lanka. Food Addit. Contam. Part B 7, 309-314. doi:10.1080/19393210.2014.938131

Jinadasa, B.K.K.K., Mahaliyana, A.S., Liyanage, N.P.P., Jayasinghe, G.D.T.M., 2015. Trace metals in the muscle tissues of skipjack tuna (Katsuwonus pelamis) in Sri Lanka. Cogent Food Agric. 1, 1038975. doi:10.1080/23311932.2015.1038975

Kojadinovic, J., Potier, M., Le Corre, M., Cosson, R.P., Bustamante, P., 2007. Bioaccumulation of trace elements in pelagic fish from the Western Indian Ocean. Environ. Pollut. 146, 548-566.

Kojadinovic, J., Potier, M., Le Corre, M., Cosson, R.P., Bustamante, P., 2006. Mercury content in commercial pelagic fish and its risk assessment in the Western Indian Ocean. Sci. Total Environ. 366, 688-700.

Matthews, A.D., 1983. Mercury content of commercially important fish of the Seychelles, and hair mercury levels of a selected part of the population. Environ. Res. 30, 305-312. doi:10.1016/00139351(83)90216-5

Mukherjee, D.P., Kumar, B., 2011. Assessment of Arsenic, Cadmium and Mercury Level in Commonly Consumed Coastal Fishes from Bay of Bengal, India. Food Sci. Qual. Manag. 2, 19-30. 